This PDF is a selection from a published volume from the National Bureau of Economic Research

Volume Title: Organizations, Civil Society, and the Roots of Development

Volume Author/Editor: Naomi R. Lamoreaux and John Joseph Wallis, editors

Volume Publisher: University of Chicago Press

Volume ISBNs: 978-0-226-42636-5 (cloth); 0-226-42636-X (cloth)

Volume URL: http://www.nber.org/books/lamo14-1

Conference Date: October 24-25, 2014

Publication Date: November 2017

Chapter Title: Adam Smith's Theory of Violence and the Political Economics of Development

Chapter Author(s): Barry R. Weingast

Chapter URL: http://www.nber.org/chapters/c13509

Chapter pages in book: (p. $51-81)$ 


\title{
Adam Smith's Theory of Violence and the Political Economics of Development
}

\author{
Barry R. Weingast
}

\subsection{Introduction}

What accounts for the differing levels of opulence across countries? Why do so many countries fail to achieve high standards of living? In short, what accounts for the differences in the "wealth of nations"? Smith poses this issue as a puzzle in both Book III of The Wealth of Nations and in his Lectures on Jurisprudence $(L J)::^{1}$ "Given the important effects of the division of labour, what an immediate tendency it has to improve the arts, it appears somewhat surprizing that every nation should continue so long in a poor and indigent state" ( $L J(\mathrm{~B}), 521)$. With persistently high levels of poverty throughout the world (Collier 2007), these questions are as relevant today as they were in Smith's time. So too, I argue, are Smith's answers.

Smith's approach is complex and multifaceted, and has yet to be fully understood. On the economic side, his answer is well known and includes the division of labor, capital accumulation, and the absence laws and regulations that encumber competition and markets, such as mercantilism and barriers to free trade. ${ }^{2}$

Yet Smith did not confine himself to economic issues when addressing the problem of development, instead turning also to politics. In The Wealth of

Barry R. Weingast is a senior fellow of the Hoover Institution and the Ward C. Krebs Family Professor in the Department of Political Science at Stanford University.

The author gratefully acknowledges Anthony Endres, Timothy Guinnane, Glory Liu, Naomi Lamoreaux, Margaret Levi, Emma Rothschild, and John Wallis for helpful comments. For acknowledgments, sources of research support, and disclosure of the author's material financial relationships, if any, please see http://www.nber.org/chapters/c13509.ack.

1. Abbreviations for Smith's works are given at the end of the text, just before the references.

2. See, for example, Aspromourgos (2009), Eltis (1975), Hollander (1973), Myint (1977), O'Brien ([1975] 2004), and Rothschild and Sen (2006). 
Nations, Smith discusses two interrelated institutions as impeding medieval European development: feudalism in Book III and the Catholic Church in Book V. I study the first in this chapter and provide an interpretation of the second from the same perspective in Weingast (2017). Smith's discussion of the transformation of feudalism and the growth of the commercial society hinges on politics, political exchange, and violence. ${ }^{3}$

As I shall demonstrate, violence is central to Smith's approach to development, especially the failure to develop. Just as modern scholars of development systematically underappreciate problems of violence (see North, Wallis, and Weingast 2009), scholars studying Adam Smith have systematically ignored or underappreciated the importance of violence in his theories of economics, politics, and development. Smith does not provide a systematic, abstract theory about the role of violence. Smith instead embeds his analysis of the political economics of development of Western Europe in a narrative, so the underlying theory is easy to miss. ${ }^{4}$ Nonetheless, we can extract a theory of Smith's political economics of development from his many discussions of this topic, especially, his analyses of European history from the fall of Rome through the rise of the commercial society. ${ }^{5}$ Smith's analysis represents what economists and political scientists call applied theory —or, in this case, an "analytic narrative" (Bates et al. 1998) — explaining the evolution of Western Europe from the fall of Rome to Smith's time.

Violence is a principal impediment to economic growth in Smith's approach. Moreover, violence arises in multiple ways; it can occur within a society as different lords, factions, religions, or regions fight one another, from hostile neighbors. It also occurs when the government plunders its citizenry. Smith's answer to the puzzle of the "slow progress of opulence" or the lack of economic development involves violence, especially in the form of government plunder: "The causes of ['slow progress of opulence'] may be considered under these two heads, first, natural impediments [such as geography], and secondly, the oppression of civil government" $(L J(\mathrm{~B}), 521)$.

Smith explains the unfortunate effects of incentives fostered by violence and the "oppression of the civil government": "In those unfortunate countries, indeed, where men are continually afraid of the violence of their superiors, they frequently bury and conceal a great part of their stock [i.e., capi-

3. Skinner $(1975,168)$, in his famous characterization of Smith's argument about development, concludes that "the motivation behind many of the most important changes was in fact political rather than simply economic."

4. Most economists studying the history of economic thought dismiss $W N$, Book III, one of the main sources of Smith's theory of political development in The Wealth of Nations. See, for example, Blaug (1978), Brue and Grant (2007), and Robbins (1998). Although Schumpeter $(1954,187)$ observed that "This third Book did not attract the attention it seems to merit," he devotes only two other sentences to this topic. Skinner $(1975,1996)$ is an obvious exception.

5. Smith presents sustained historical analyses in $W N$, Book III, in Book V on the medieval church, and in both $L J(\mathrm{~A})$ and $L J(\mathrm{~B})$. 
tal], in order to have it always at hand to carry with them to some place of safety, in case of their being threatened with any of those disasters to which they consider themselves as at all times exposed" ( $W N$ II.i.30-31, 284-85).

The purpose of this chapter is to develop Smith's answer to the questions asked at the outset about the differences in the wealth of nations. His analysis can be summarized as follows. The invasions of the Roman Empire ultimately forced it to collapse, and with it, the Roman system of property rights, division of labor, and exchange. Smith characterizes the consequences of the invasions and the violent environment that followed, "The rapine and violence which the barbarians exercised against the antient inhabitants, interrupted the commerce between the towns and the country. The towns were deserted, and the country was left uncultivated, and the western provinces of Europe, which had enjoyed a considerable degree of opulence under the Roman empire, sunk into the lowest state of poverty and barbarism" (WN III.ii.1, 381-82).

Eventually, the feudal form of governance arose. ${ }^{6}$ In this system, land represented the means to power, wealth, and security. Violence, as Smith emphasizes, was a constant presence. The most powerful lords typically obtained the largest and best land, allowing them to support many retainers and large armies. The lords constantly fought each other and the king. All organizations in the feudal era were closely connected to the state and supported the ability of the king and lords to project force.

The feudal society can be characterized by the "violence trap" (Cox, North, and Weingast 2017), ${ }^{7}$ which works as follows. Economic growth requires both capital accumulation and economic integration that accompany an increasing division of labor; moreover, economic integration raises the costs of fighting. But violence threatens the value of the investments necessary for economic integration, especially integration across regions or factions that might fight each other. Smith again and again explains that, given the risk of violence, rational investors will not invest in economic integration:

In the infancey of society, as has been often observed, government must be weak and feeble, and it is long before it's authority can protect the industry of individuals from the rapacity of their neighbours. When people find themselves every moment in danger of being robbed of all they possess, they have no motive to be industrious. There could be little accumulation of stock, because the indolent, which would be the greatest number, would

6. Smith argues that allodial arrangements arose following the fall of Rome. Eventually the feudal system replaced the allodial one. My analysis begins at this point, once the feudal system has been established ( $W N$ III).

7. Poverty traps are common in economics as explanations of the persistence of poverty and the lack of economic development (Azariadis and Stachurski [2005] provide a recent survey). 
live upon the industrious, and spend whatever they produced. Nothing can be more an obstacle to the progress of opulence. $(L J(\mathrm{~B}), 522)$

Given these incentives, the violence trap is self-sustaining and difficult to escape; most incremental changes - a modest increase in investment or economic integration - are insufficient to escape the trap. ${ }^{8}$ Set in the context of Smith's arguments about violence, Smith's logic reflects the violence trap. Hence the feudal equilibrium of violence and low growth was stable.

How did Western Europe escape the violence trap? According to Smith, the rise of towns represented the essential step in the political-economic development of Europe. In the midst of the feudal equilibrium, the king and town (small groups of traders) engaged in a political exchange, forming a coalition against their common enemy, the local lords. The king granted the towns rights of self-governance, control over a wide array of local organizations, trading, and defense in exchange for taxes and military service. The new system represented a nonincremental change that simultaneously produced liberty, commerce, and security, allowing the town to escape the violence trap and a positive feedback system with increasing returns. ${ }^{9}$

As the towns grew, they extended their reach into the countryside, transforming self-sufficient agriculture into communities with specialists producing food and raw materials for the towns and, often, long-distance trade. A necessary component of the towns' escape from the violence trap is that the towns gained military superiority relative to the local lords. This superiority allowed them to protect property rights, trade, amass wealth, and grow opulent while defending themselves against the arbitrary exactions and rapacious violence of the local lords - and also the king.

To explain the towns' escape from the violence of the feudal basic natural state, we need two different but complementary arguments, one at the microinstitutional level involving organizations, one at the macroinstitutional level involving political exchange, and the (small "c") constitution. Addressing changes at both the micro and macro level is necessary to understand the rise of and economic growth of towns.

This chapter proceeds as follows: In the second section, I present elements of Smith's theories of the political economics of development. Section 2.3 presents Smith's theory of the feudal equilibrium, explaining why feudalism was stable even though it prevented growth. Section 2.4 provides a deeper understanding of violence and its implications for Smith's work. Sections

8. Smith understood the logic of poverty traps. For example, he argued that: "This is one great cause of the slow progress of opulence in every country; till some stock be produced there can be no division of labour, and before a division of labour take place there can be very little accumulation of stock" $(L J(B) 287,522)$.

9. "Increasing Returns and Economic Progress"- the title of Young's (1928) well-known paper - have long been a part of the literature on Smith. See also the "virtuous circle" of Macfarlane (2000) and Rothschild and Sen (2006, 334-37). 
2.5 and 2.6 explain his theory of the towns' escape from that equilibrium. My conclusions follow.

\subsection{Elements of Smith's Theory of the Political Economics of Development}

In Book III of The Wealth of Nations, and in parallel sections of his Lectures on Jurisprudence, Adam Smith provides a theory of the political economics of development of Western Europe. The theory is easy to miss because Smith embeds his approach in a historical narrative. A small but important group of Smith scholars examine Book III carefully, helping to extract Smith's theoretical argument. In this section, I draw on these works to explore several general theoretical propositions about the political economics of development proposed by Smith in his historical jurisprudence focusing on Western Europe. ${ }^{10}$

In reporting on Smith's understanding of development in Western Europe, I take the history as Smith conceived it, not as we think of these events today. Indeed, the importance of Smith's history is not its fidelity with actual fact, but how Smith uses it to devise a theoretical explanation for the events of this era.

\subsubsection{Violence}

Adam Smith understood violence to be a first-order problem hindering development; any solution to the development problem, therefore, had to involve limiting violence. Smith studies several types of violence, including predation by the government, plunder by neighbors, and invasions by distant foes. These sources of violence reduce the incentives for industry, saving, investment, and specialization. To develop, a society must therefore mitigate these sources of violence.

\subsubsection{The Feudal Equilibrium}

Smith shows why the violence of the feudal era created a stable politicaleconomic equilibrium of very low growth. The high level of violence forced a particular form of economic, political, and social organization with the ability to protect local communities and to project force when the occasion arose. The rules of the game were designed to further the decentralized military organization of local government. As argued in section 2.4, property rights in land, the most valuable asset in medieval times, were designed to promote security and other military goals, not economic efficiency.

10. See, for example, Skinner (1975), Winch (1978, ch. 4), Moss (1979), Haakonssen (1981, 165-71), Henderson (2006, chs. 7-8), Aspromourgos (2009, ch. 5), Hont (2009, 2015), and Kennedy (2010, chs. 5, 8, and 9). 
The institutions of feudalism, including property rights, had economic consequences. Because of the risk of violence and plunder, people rationally avoided hard work, initiative, savings, and investment. "[T]he occupiers of land in the country were exposed to every sort of violence. But men in this defenceless state naturally content themselves with their necessary subsistence; because to acquire more might only tempt the injustice of their oppressors" (WN III.iii.12, 405). ${ }^{11}$ As we will see, Smith's views of the feudal equilibrium were a form of a violence trap of no growth (Cox, North, and Weingast 2017). The constant risk of violence deterred investment and hence economic growth. Given the omnipresent security concerns, incremental steps at reform were inadequate to alter this setting.

\subsubsection{Political Exchange and the Escape from the Violence Trap}

Smith explains that the escape from the violence trap was nonincremental. King and town made an alliance against their common enemies, the local lords. The political exchange accompanying the alliance redefined rights and political authority; this exchange therefore encompassed an explicit revision of the constitution governing the towns. The alliance made the king more powerful - through revenue and military service from the towns - and the towns gained a nonincremental increase in control over their own destiny.

Smith suggests three necessary conditions for the growth of towns following the political exchange with the king. These features of town organization reflect the creation of market infrastructure that constitute "the economic role of political institutions" (Weingast 1995). The first required that the town became capable of providing for its security. Given the plunder of the great landholders, the towns' survival required that they gain a local advantage in fighting. Without this advantage, the towns could not have fended off plunder. Commerce was also necessary, for it provided the gains from exchange and hence the engine of town growth. With growth came the means for financing the towns' public goods and market infrastructure such as order, security, and justice, including strong property rights. Liberty - in the form of strong property rights, a system of justice, and the absence of predation - was also necessary; liberty provided economic actors, for example, with the incentives to save, invest, and take initiative.

The new arrangements were not solely a reconfiguration of existing feudal organization. They represented both a nonincremental change in the nature of organizations and of the tools available for the towns' organizations. Towns created the organizations of a working government, including court systems, guilds, governing bodies, military organizations, and various business organizations.

11. Further, a "person who can acquire no property, can have no other interest but to eat as much, and to labour as little as possible" (WN III.ii.9, 387-88). 


\subsection{The Feudal Equilibrium, or the "Lowest State of Poverty and Barbarism"}

Smith argued that violence was the principal impediment to both economic growth and the escape from poverty. ${ }^{12}$ Smith applied his approach to the history of the West from prehistoric times to his own $(L J)$. Along the way, he discusses the impediments to greater opulence.

I begin with Smith's observations about the consequences of the fall of Rome. For several centuries prior to the invasions, the Roman Empire sustained sufficient security to foster a substantial division of labor, specialization and exchange, and hence opulence. The various invasions destroyed this stability, with disastrous economic effects.

Having displaced the Romans, the invaders settled down. Property in this world was more than an economic asset. As the principal means of supporting warriors, property also represented power. Those who held higher quality and larger tracts of land commanded larger armies.

No one, Smith says, could keep the peace. Kings were insufficiently powerful to enforce their authority, law, and order throughout their domain. The result was violence and disorder. The great lords "were always at war with each other and often with the king, their whole power depended on the service of their retainers and tenants" $(L J(\mathrm{~A})$ iv.126-27, 249).

At the microinstitutional level, this setting had implications for local political-economic organization. Because kings could not keep the peace within their realm, they were forced of necessity to concede local political control to the lords ( $L J(\mathrm{~A})$ iv.119, 246). The great landlords ruled their territory, serving as executive, legislature, and judge; they also led their tenants in war. ${ }^{13}$ This setting did not encourage markets or economic growth.

Smith characterized the feudal world as violent and predatory, with little overall growth. Most people lived at subsistence, with minimal degrees of trade, division of labor, and specialization and exchange. Centered around the manor, the local agrarian economy was largely self-sufficient and based on custom with little monetary exchange. The local lord captured most of the local surplus, converting it into security through local military organization (North and Thomas 1973) and by dividing the surplus among retainers in exchange for various service obligations, especially military obligations.

12. This section draws on work of: Aspromourgos (2009, ch. 5), Bell (1992), Haakonssen (1981, 165-71), Henderson (2006, chs. 7-8), Hollander (1979), Hont ([1989] 2005), Kennedy (2010, chs. 5, 8, and 9), Winch (1978, ch. 4), and especially Skinner's (1975) classic treatment.

13. "In those disorderly times, every great landlord was a sort of petty prince. His tenants were his subjects. He was their judge, and in some respects their legislator in peace, and their leader in war. He made war according to his own discretion, frequently against his neighbours, and sometimes against his sovereign" ( $W N$ III.ii.3, 383). 
Investment, in Smith's view, was generally fruitless because of violence and predation. Indeed, to invest, improve, and better one's condition was to become a target of plunder. Violence and plunder meant that people focused on subsistence "because to acquire more might only tempt the injustice of their oppressors" ( $W N$ III.iii.12, 405). Those working the land could not acquire property. They had little incentive to work hard, indeed to work at all beyond their own maintenance ( $W N$ III.ii.9, 387-88).

More generally, Smith argues that to be independent individuals and groups needed to be powerful - that is, to possess their own violence potential to protect themselves from the violence of others. If they did not possess power, they were forced to ally with a powerful group for mere survival ( $W N$ III.iii.8, 401).

Access to organizations in this world was limited. In a primitive subsistence economy, economic and military organizations were parallel. The church was also an organization of organizations, but Smith separates his discussion of the church from his discussion of feudalism and the growth of towns. ${ }^{14}$ As just noted, government was not well articulated, but centered on the local lords, who ran the local polity as their personal property.

More generally, the economic organization under the lords paralleled the military hierarchy. The great lords commanded considerable land. They granted rights to work the land to their vassals and their dependents. Members of the hierarchy who were also part of the military organization oversaw the local economic production on the land gained from the king. As Smith observes, these men were specialists in violence, not professional managers of agriculture estates and production.

\subsubsection{Economic Effects of the Feudal Equilibrium}

At the macroinstitutional level, violence and predation had clear economic effects. The violence associated with the invasions and the fall of the Roman Empire produced a downward economic spiral as exchange - the basis for the division of labor and hence of opulence-became risky and vulnerable. Trade and communication fell precipitously. Speaking of the great lords, Smith says: "Their lawless and freebooting manner of life also destroyed all the commerce and industry of the former inhabitants, who were obliged to leave the cities and seek possessions and protection in the lands of the several lords" $(L J(\mathrm{~A})$ iv.124, 248). Put simply, plunder inhibited political-economic development. ${ }^{15}$

14. For example, in The Wealth of Nations, Smith discusses feudalism and the rise of towns in Book III and the church in Book V.

15. "In a rude state of society there are no great mercantile or manufacturing capitals. The individuals who hoard whatever money they can save, and who conceal their hoard, do so from a distrust of the justice of government, from a fear that if it was known that they had a hoard, and where that hoard was to be found, they would quickly be plundered" ( $W N$ V.iii.9, 911). 


\subsection{A Deeper Understanding of Violence and Its Implications for Smith's Arguments}

Violence is a strategy by which some groups obtain resources through plundering the efforts of others (Hirschleifer 1994; Dixit 2004). ${ }^{16}$ In what follows, I draw on the conceptual framework in North, Wallis, and Weingast (2009), as extended by Cox, North, and Weingast (2017). As Cox, North, and Weingast show, intrastate violence is remarkably high in today's developing world. Violent takeover of leadership, for example, occurs once every seven years for the median developing country in the poorest half of the distribution of countries by income. From Smith's discussion, the feudal world was, if anything, more violent.

\subsubsection{The Logic of Violence}

The framework holds that developing states, past and present, must devise a means of mitigating the manifestation of violence, even if they cannot rid themselves of multiple and independent sources of violence. How they do so affects their ability to develop. As with all developing countries, past and present, the feudal organization was a natural state. The two central features of natural states are that there exists multiple individuals and groups with violence potential, and that these states limit violence by inducing individuals and groups with violence potential to cooperate rather than fight. The principal mechanism is rent creation. Natural states create and limit access to privileges, state services, and organizations; to create and support these rents, they limit competition in seemingly endless ways.

Natural states use these rents to induce cooperation. They distribute the rents to powerful individuals and groups with violence potential. Because violence typically lowers rents, rents targeted to those with violence potential makes the latter better off than fighting. North, Wallis, and Weingast (2009) call these societies natural states because they have been by far the dominant way of organizing states throughout history, and this observation remains so today.

A simple bargaining model of the natural state helps elucidate the natural state logic (see Cox, North, and Weingast 2017). Suppose two groups with violence potential compete for control of the state and its potential for producing surplus. The two groups face a choice; they may either fight or

16. Students of development fail to systematically incorporate violence in their approaches (as North, Wallis, and Weingast [2009] emphasize). For example, almost all models of the political development of the state assume that the state is a unified actor with monopoly control on violence (Barzel 2002; Bates 2001; Levi 1988; North 1981, ch. 5; Olson 1993; Tilly 1992). This reads the solution to the problem of multiple sources of intrastate violence back into history long before the problem was solved. These models therefore cannot explain the emergence of the modern, developed state with a monopoly on violence since they assume the result from the outset. To understand this aspect of development we must start elsewhere. 
bargain to an agreement. The two groups may differ in their military capacities, so the probability that each wins a fight may differ. Finally, fighting is costly, so each pays a price to exercise violence. The bargaining approach implies that each group can assess their expected value of fighting.

To maintain peace and cooperation among the powerful, the no-fight conditions must hold: that is, the rents each receives from the natural state must exceed the expected value of fighting. If the no-fight conditions hold for both groups, then both are better off cooperating. Under these conditions, the natural state is a stable equilibrium, at least in the short term. In contrast, if the no-fight condition fails for either group, then this group is better off resorting to violence, so peace and cooperation is not an equilibrium in the natural state. The no-fight conditions also imply that more powerful groups - those with larger expected values of fighting - must, in turn, receive more privileges and rents to make cooperation the preferred choice over fighting.

This bargaining framework has a dynamic element. As North (2005) observed, the world is constantly changing, even nonergodic. All states experience episodic shocks, such as changes in relative prices, changes in military technology, or the appearance of a hostile and threatening neighboring regime. In natural states, these shocks often alter the relative power of groups with violence potential.

Sufficiently large shocks in a natural state's environment alter the distribution of relative power so that the no-fight conditions no longer hold. These shocks break down the old bargaining agreement so that the parties must bargain to reallocate benefits or risk violence. Absent any change in the allocation of benefits, at least one group now prefers to fight.

What happens next depends on information and incentives. If the effects of the shock on power are common knowledge, then it is possible for the two parties to reach a new bargaining agreement to prevent violence by transferring some rents and privileges from one player to the other. To succeed, the renegotiation must reestablish the no-fight conditions given the new circumstances.

Yet peaceful adjustment is not always possible. A problem arises when the common knowledge assumption about the effects of a shock fails. In this case, three major problems hinder renegotiation: low economic costs of violence, commitment problems, and asymmetric information. For example, given uncertainty about the implications of a shock, asymmetric information may lead one party to believe itself far more powerful after a shock than the second party believes the first to be. If so then the minimum bargain the first is willing to accept can be higher than the maximum the other is willing to grant. As Fearon (1995) demonstrates in his classic paper on war, fighting is inevitable under these circumstances (see also Powell 1999; Muthoo 1999). 


\section{Implications of the Framework for Political-Economic Development}

The main value of the bargaining framework is that it helps us to understand the role of violence in Smith's approach to the failure of opulence. Put simply, a violence trap prevents nearly all natural states from developing, feudalism in particular. The need to solve the problem of distributed violence potential leads natural states to policies creating rents and limiting access to organizations. These policies are necessary to establish the nofight conditions. They also prevent development. An important route to both development and nonviolence is greater economic integration, which raises the costs of intrastate violence. But in the face of distributive violence potential, investments in greater economic integration are risky; their value falls precipitously in the event of violence.

Herein lies the violence trap. Economic integration is necessary to raise the costs of violence, but people will not make investments in economic integration because the threat of violence makes the investments too risky. These states are caught in a low-growth, low-investment, nondevelopment equilibrium. The great difficulty for development is moving from the violence trap to economic integration and development.

\subsubsection{The Feudal Equilibrium as a Violence Trap}

We can understand why violence is an impediment to growth and development. The form of property rights, the degree of open access to organizations, and, generally, the political manipulation of markets reflect the degree of violence in a society. Societies secure from violence threats are capable of producing property rights in which economic agents have incentives to invest in physical, financial, and human capital. An expanding division of labor and economic integration follows. In contrast, societies that face an everyday threat of violence must organize themselves differently. In very violent societies, leaders and landholders must of necessity be a warrior class, not economic managers. To support military organization, Smith explains, property rights in land must differ considerably from those that maximize the value of production. Rights develop that foster the ability of the lord to project force.

The bargaining model discussed in the previous subsection applies to the feudal setting. Regularly changing circumstances, asymmetric information, and the absence of credible commitments plagued the possibility of agreements to maintain peace. In modern terms, the feudal society represented an equilibrium in the sense that, though the fortunes of individual lords changed over time, the basic structure of the political and economic arrangements remained stable.

At the microinstitutional level, military competition drove the economic, political, and social organizational structure. The constant threat to security meant that lords who failed to capture most of the surplus and use it to main- 
tain their violence potential became vulnerable. The feudal organization thus had features of an arms race. All the lords would be better off if they could, somehow, agree not to fight and to invest instead. But this bargain was vulnerable to defection. A single lord who continued to extract maximum rents for military purposes had a military advantage over other lords who did not. Further, because the king was insufficiently powerful, he could not easily subdue a large coalition of the lords. Their bargain-distributing political power reflected this fact; hence, the king was forced to allow the lords political control over their domains.

The militarized environment had implications for the macroinstitutional level; this environment afforded few gains from specialization and exchange, and it also limited the possible organizations. The main agricultural products, such as grain, could not be carried profitably far over land. The absence of a state that could provide order and security (WN III.iv.9, 418) meant great risks to specialization and exchange as transporting items risked being stolen in the attempt.

Virtually all secular organizations had to be associated with the local lord, or else they were destroyed or captured with their assets expropriated. As described by Smith, the feudal equilibrium reflects the logic of the natural state. Outside of the church, organizations existed largely to the extent they strengthened the violence capacity of the local lords. ${ }^{17}$ The feudal hierarchy illustrates this, with its comingling of the organization of military force, the system of vassalage, the nature of rights in land (discussed in the next subsection), and the form of labor organization (which Smith considers a form of slavery). All these organizational elements reflected the feudal logic of violence. As we have seen, this environment of political opportunism and predation provided poor incentives for saving and investment. Violence prevented the accumulation of stock, without which the economy could not grow.

The bargaining approach discussed in the previous subsection suggests that the rents and privileges were distributed according to the no-fight conditions and adjusted as shocks and changing circumstances required. When bargaining failed to make adjustments according to the no-fight conditions, violence occurred. Agreements between lords and the king, among lords, or between lords and their retainers were constantly broken or adjusted unilaterally. Increases in inclusion could occur only if it reflected new sources of violence potential.

In North, Wallis, and Weingast's (2009) terms, regular violence meant the absence of perpetuity and impersonality. Perpetual institutions stand in the way of natural state adjustments to changing circumstances, and impersonality implied violations to the no-fight conditions. The natural state

17. I discuss Smith's argument about the church's coexistence with the secular lords in Weingast (2017). 
bargaining setting requires regular adjustment of the rules and privileges to changing circumstances. The failure of perpetuity and impersonality, in turn, meant the absence of the rule of law in natural states (Weingast 2010). Needless to say, this world was poor, violent, and undeveloped.

\subsubsection{Property Rights in Land}

At the microinstitutional level, land represented power in the feudal society. The form of property rights and the organizations supported by the feudal system was central to the feudal society's survival. ${ }^{18}$ The form of rights privileged security needs over efficiency. In Smith's argument, the rights in land are endogenous to the larger feudal environment. He explains why modern, private property rights in land could not be sustained. Moreover, the form of property directly affected - and limited - the types of organizations that could be sustained.

Modern, developed open-access orders have a complex system of legal infrastructure that facilitates exchange and efficient allocation of land based on a strong system of property rights. Some of the characteristics of this legal infrastructure include: (a) strong protections from expropriation and plunder by the state and by others; (b) a system of titling, ownership rules, and a judiciary to enforce them; (c) the right to devise property by will among heirs; (d) rights of free alienation of land with an absence of encumbrances on selling the land and to whom the land may be sold; and (e) a legal system that enforces contacts, including the exchange of land (see, e.g., Posner 2006; Barzel 1997; Alston et al. 2016). Each of these characteristics facilitates the exchange of land from lower- to higher-valued users; in particular, to individuals who would improve the land.

The feudal system of property rights in land involved none of these characteristics. The problem of violence and the need to support military organizations to maintain security forced wholesale deviations from the set of characteristics just outlined. Lords regularly fought one another, and the winners often forced the losers to transfer portions of their land; condition (a) therefore failed. The absence of a government and a judicial system implies that conditions (b) and (c) failed.

Security required that a wide range of restrictions be imposed on the right of property holders to alienate their property or to devise property by will. In particular, primogeniture arose, preventing the division of the land among several sons; so too did entails, which prevented a landowner from dividing his property and alienating some of the pieces. The feudal system of land rights dramatically restricted the transfer of land from low-valued users to higher-valued users, and, also, of markets to engineer movement toward the optimal organization of parcels and generally more efficient production.

18. The discussion of Smith's views of property rights in land draws on Aspromourgos (2009, ch. 5) and Henderson (2006, ch. 8). 
Smith explains why this system was stable. The logic involves violence, especially the failure of conditions (c) and (d). ${ }^{19}$ In economies where land is largely a means of subsistence, characteristics of land law can reflect characteristics (a)-(e) noted above. In contrast, "when land was considered as the means, not of subsistence merely, but of power and protection, it was thought better that it should descend undivided. . . . The security of a landed estate, therefore, the protection which its owner could afford to those who dwelt on it, depended upon its greatness. To divide it was to ruin it, and to expose every part of it to be oppressed and swallowed up by the incursions of its neighbours" (WN III.ii.3, 382-83). Smith's central insight is the conclusion in the last sentence: to divide the land was to ruin it as a means of security.

The relationship between lord and retainer, organizations, and power all centered around land. The feudal society bundled rights to land with service obligations to the lord as part of the organization of the feudal hierarchy. Individuals did not own the land in the modern sense of clear title with an absence of the ability of the government or other individuals to force the property holder to give up the land. Instead, the organization of economic production paralleled the military organization.

Many of the most inimical features of feudalism's rights in land can be explained by their role in supporting violence potential. These constraints on property improved local security even though they harmed the local economy by restricting land from moving to higher-valued uses. Adam Smith argued that the emergence, role, and stability of primogeniture, entails, and wardship all improved a lord's ability to project force and maintain local security. ${ }^{20}$

Primogeniture prevented lords from dividing their property among many heirs, requiring instead that all of a lord's property go to his firstborn son. In the violent feudal society, primogeniture enhanced security. One larger parcel had clear advantages, in Smith's account, to the same land divided up into many smaller parcels. Because each locality had to provide for its own security, small properties were not secure. They "could not defend [themselves] and must be entirely dependent on the assistance of some of the neighbouring great men ... [A]s the only security in the other case was from the strength of the possessor, small property could be in no security" ( $L J$ i.130-31, 55). Smith then draws the main implication: "If therefore an estate which when united could easily defend itself against all its neighbours should be divided in the same manner as moveables were, that is, equally

19. The example of the deviation of rights in land from those best suited to markets to those best suited for feudalism illustrates Smith's contention that Europe did not take the natural path to opulence, but deviated from that path considerably ( $W N$ III.i.8-9, 380).

20. Ober and Weingast (forthcoming) show that ancient Sparta failed to employ this form of property rights. Over a series of generations, Sparta lost the ability to defend itself. 
betwixt all the brothers, it would be in no state of equality with those to whom it was before far superior" $(L J$ i.131, 55).

The same logic applies to entails. If primogeniture preserved a lord's estate at time of death, entails preserved the estate during the lord's life. Entails "preserve[d] a certain lineal succession, of which the law of primogeniture first gave the idea, and to hinder any part of the original estate from being carried out of the proposed line either by gift, or devise, or alienation; either by the folly, or by the misfortune of any of its successive owners" (WN III. ii. 5,384$)$.

Wardship, the practice whereby the king or lord appointed another the right to use the land of an estate while an heir remained a minor, provides a variant on this logic. Though hated by the landed elite, wardship represented a solution to an important security problem. Recall that vassals of a lord held land by virtue of an exchange to supply military and other services. A problem arose when an heir as ward could not meet the feudal obligations associated with his land. Wards could not provide the required leadership of the estate's military organization and, consequently, failed to provide the obligated service to the lord. Given the constant threat of violence, no lord could afford to have property in his domain that failed to contribute to his power and security. Wardship as a form of organization allowed the lord to assign rights to run the property to another person for the duration of the wardship in order to finance violence potential and meet the military service obligations to the lord that accompanied the ward's property.

To summarize, the feudal world was violent, stable, and undeveloped. We characterize this world as a "violence trap"; or, in somewhat different terms, a "vicious circle of poverty" (Macfarlane 2000,98) and the failure to become a "virtuous circle" (Rothschild and Sen 2006, 336).

\subsection{From Feudalism to the Commercial Economy}

The transformation of Western Europe out of feudalism began with the chartering of towns, creating a significant, nonmarginal constitutional and organizational change affecting a small but important subset of the feudal society. These changes had unintended consequences, helping specific parts of Western Europe - notably the towns and the territory surrounding them - to escape the violence trap. Small-time traders during the feudal era, typically in "servile, or very nearly servile" relations to local lords, paid the lords for the right to trade ( $W N$ III.iii.2, 397-98). ${ }^{21}$ These traders, often liv-

21. Smith says in $L J(\mathrm{~A})$ (iv.142-43, 255-56) that the burghers: "were at first slaves or villains who belonged to a certain lord or master to whom they paid a summ of money for the liberty of trading. They lived in small towns or villages for the convenience of trading, but in but very small numbers." 
ing together in tiny towns, worked under remarkably unfavorable conditions of violence and predation. Potentially significant gains existed from specialization and exchange in long-distance trade. But the feudal system's threat of violence and plunder prevented these gains from being realized. The "wealth which [the traders] did manage to accumulate under such unfavorable conditions was subject to the arbitrary exactions of both the king and those lords on whose territories they might happen to be based on through which they might pass" (Skinner 1975, 162, citing WN III.iii.2, 397-98).

To take advantage of profitable opportunities in long-distance trade, the towns and traders needed various investments (port facilities, ships), a range of new organizations (judicial, firms, labor, markets, military), and nonmarginal increases in security. Increased security, in turn, allowed the towns to govern themselves, producing islands of perpetuity, impersonality, and order for elites. Towns that failed to produce order were at a disadvantage relative to their competitors, hence less likely to survive. The more secure political environment fostered investment, specialization and exchange, and economic expansion. It also fostered organizational innovation. Rothschild and Sen $(2006,334-37)$ capture this logic: "The progress of opulence can be seen as a virtuous circle, in which legal and political improvement leads to economic improvement, and economic improvement, in turn leads to further improvement in political and legal institutions."

I explore Smith's logic of the towns' escape from the violence trap in four stages; I evaluate Smith's logic in the following section.

\subsubsection{Political Exchange between King and Town}

Smith's explanation for the escape from feudalism involves three distinct groups: the king, the lords, and the traders. Under feudalism, as we have seen, the king and lords were constantly fighting, and each plundered the towns. Political uncertainty and the constant threat of predation from the lords hindered the towns' ability to capture the gains from long-distance trade.

The political exchange between town and king created a coalition against a common enemy. Importantly, this political exchange allowed the towns to initiate the transformation out of the no-growth feudal equilibrium and to capture the benefits of specialization, exchange, and long-distance trade.

Smith makes four points about this political exchange, which I disaggregate and number:

1. In order to understand [the kings' grant of independence to the towns], it must be remembered, that in those days the sovereign of perhaps no country in Europe, was able to protect, through the whole extent of his dominions, the weaker part of his subjects from the oppression of the great lords.

2. The inhabitants of cities and burghs, considered as single individuals, had no power to defend themselves: but by entering into a league of 
mutual defence with their neighbours, they were capable of making no contemptible resistance.

3. The lords despised the burghers. ... The wealth of the burghers never failed to provoke their envy and indignation, and [the lords] plundered them upon every occasion without mercy or remorse. The burghers naturally hated and feared the lords. The king hated and feared them too; but though perhaps he might despise, he had no reason either to hate or fear the burghers.

4. Mutual interest, therefore, disposed [the burghers] to support the king, and the king to support them against the lords. They were the enemies of his enemies, and it was his interest to render them as secure and independent of those enemies as he could. By granting them magistrates of their own, the privilege of making bye-laws for their own government, that of building walls for their own defence, and that of reducing all their inhabitants under a sort of military discipline, he gave them all the means of security and independency of the barons which it was in his power to bestow. Without the establishment of some regular government of this kind, without some authority to compel their inhabitants to act according to some certain plan or system, no voluntary league of mutual defence could either have afforded them any permanent security, or have enabled them to give the king any considerable support. ( $W N$ III.iii.8, 401-2)

Let's unpack this passage into Smith's four points. First, Smith describes the initial conditions involved a natural state logic based on violence potential. Autocratic lords oppressed merchants within their domain. Second, Smith suggests how new possibilities arose for the defense of towns against the lords. Third, Smith discusses the interests of the three parties, king, lord, and town, explaining that mutual self-interest drove the king and town together in alliance against their common enemies, the local lords. And finally, Smith explains the basis for political exchange between king and town in which the king granted the town political freedom in exchange for fixed taxes and military support.

The feudal environment afforded the possibility for generating substantial gains for the town through long-distance trade, greater specialization and division of labor, and exchange. These opportunities provided the king and the towns with strong incentives to engineer a political exchange: The king granted the town political freedom, self-governance, and independence in exchange for financial and military support against the barons ( $W N$ III. iii.3, 399). This freedom allowed the town to provide its own rules, property rights, governance, justice, the rule of law, and security. All of these activities required organizations, and the town itself can be thought of as an organization of the organizations, as I discuss in the next section. The right to build walls and military organizations allowed towns to protect themselves against the local lords, but also the king.

In exchange, the towns lent the king military support and paid the king taxes, which were to be fixed for all time, lowering the king's ability to expro- 
priate the gains of investment through ex post rises in taxes. According to Smith, the tax agreement became perpetual and impersonal (WN III.iii.4, 400).

\subsubsection{Towns Escape the Violence Trap}

The advantage of the political exchange to members of the town is obvious: they obtained greater security, protection for their investments, and growth of their economy. The king gained a security alliance with the towns and larger resources up front with which to deal with the local lords.

These agreements led to the first real emergence of liberty in late medieval Europe. "Order and good government, and along with them the liberty and security of individuals, were, in this manner, established in cities at a time when the occupiers of land in the country were exposed to every sort of violence" ( $W N$ III.iii.12, 405). Smith next explains his insights, ideas now central to modern political economics of development. When men capture the fruits of their efforts, they exert themselves to "better their condition" and to "acquire not only the necessaries, but the conveniencies and elegancies of life." In contrast, in the feudal environment, people had little incentive to work hard. Those living near towns who managed to accumulate a small amount sought protection of the towns as sanctuaries (WN III.iii.12, 405). ${ }^{22}$

Another aspect of the political exchange helped the towns protect their interests. As the towns grew richer and more powerful, the king granted the burghers political representation in "the general assembly of the states of the kingdom," in part to counterbalance the great lords. The towns' charters, backed by their growing economic and military power, meant that the king could impose no additional taxes (beyond those specified by charter) without the towns' consent ( $W N$ III.iii.11, 404).

\subsubsection{The Towns Incrementally Extend Their Reach into the Countryside}

Smith titled chapter IV of Book III, "How the Commerce of the Towns Contributed to the Improvement of the Country" ( $W N$ III.iv, 411). As the towns grew, he explains, they had incentives to expand their reach — bringing military security, the security of property rights, and markets - into the surrounding countryside.

Smith argued that the towns' military advantage over the local lords fostered the extension of the towns' reach. The towns more easily coordinated men, weapons, and supplies, and they could assemble their forces more quickly than the local lords. "The militia of the cities seems, in those times,

22. Smith notes the result with some irony, "the sovereigns of all the different countries of Europe ... have ... voluntarily erected a sort of independent republics in the heart of their own dominions" ( $W N$ III.iii.7, 401). 
not to have been inferior to that of the country, and as they could be more readily assembled upon any sudden occasion, they frequently had the advantage in their disputes with the neighbouring lords" (WN III.iii.10, 403).

Over time, the towns became far richer than the local lords, improving the towns' military advantage and providing an expanding area secure from predation. These changes, in turn, transformed local agriculture surrounding the towns. Property rights and security fostered growing specialization and exchange, helping to transform self-sufficient farmers into market specialists. Agricultural products and raw materials went to the towns for local consumption and production, and, often, for long-distance trade, while the products of the towns moved to the countryside. Allen $(2009,106)$ explains the reciprocal and positive-feedback relationship; the growth of cities fostered the growth of local agriculture production, and, at the same time, a more productive agriculture led to greater urbanization.

\subsubsection{The Growing Reach of the Towns Transformed Economic and Social Relations, Undermining Feudalism}

Subduing the nearby lords had far-reaching though unintended consequences as the lords became integrated into the towns' commercial and security umbrella. The towns' military superiority solved the security problem for nearby lords within the towns' security umbrella. This umbrella, in turn, diminished the local lords' need for military organization and defense against their neighbors. In the new security environment, the lords reorganized their local polities, dismantling the organization of society around the projection of military force. Retainers, once a necessary part of security, became an expensive burden with little benefit, so the lords demilitarized and let go of their retainers ( $W N$ III.iv.10, 418).

The nonincremental changes in local security, Smith argues, had further unintended consequences in the countryside surrounding the towns: "commerce and manufactures gradually introduced order and good government, and with them, the liberty and security of individuals, among the inhabitants of the country, who had before lived almost in a continual state of war with their neighbours, and of servile dependency upon their superiors. This, though it has been the least observed, is by far the most important of all their effects" (WN III.iv.4, 412). ${ }^{23}$ As the towns expanded their security and legal umbrella, a "regular government was established in the country as well

23. Further, "A revolution of the greatest importance to the publick happiness, was in this manner brought about by two different orders of people, who had not the least intention to serve the publick. To gratify the most childish vanity was the sole motive of the great proprietors. The merchants and artificers, much less ridiculous, acted merely from a view to their own interest, and in pursuit of their own pedlar principle of turning a penny wherever a penny was to be got. Neither of them had either knowledge or foresight of that great revolution which the folly of the one, and the industry of the other, was gradually bringing about" ( $W N$ III. iv.17-18, 422). 
as in the city, nobody having sufficient power to disturb its operations in the one, any more than in the other" ( $W N$ III.iv.14, 421).

The security umbrella fostered a revolution in the organization of the countryside surrounding the towns. The lords, seeking to increase their consumption, had incentives to grant - and tenants had incentives to pay forlonger leases, which encouraged investment, specialization, and exchange (WN III.iv.1-2, 410; III.iv.13, 421). The lords leased out their lands and lived off the rents combined with the profits from the portion of their estates that they managed directly. In the absence of expensive military obligations, local lords became consumers. In taking advantage of the growing opportunities provided by the towns' commercial economy, the lords found luxury items especially alluring. Smith derisively explains how the lords gave up their political power for trinkets and baubles ( $W N$ III.iv.15, 421).

Smith's central pillars of economic growth - the division of labor and capital accumulation - appear throughout this process. The towns transformed self-sufficient farmers into specialists in complex and growing markets (WN III.iv.13, 420-21). Greater division of labor made these farmers better off. Improvements in property rights, such as better rules on devising property upon death, slowly emerged and fostered a more efficient allocation of land. At the same time, prosperous burghers moved into the countryside, bringing with them their ambitions and their culture of investment, specialization, and exchange ( $W N$ III.iv.3, 410).

The consequences were revolutionary. "[W] hat all the violence of the feudal institutions could never have effected, the silent and insensible operation of foreign commerce and manufactures gradually brought about. These gradually furnished the great proprietors with something for which they could exchange the whole surplus produce of their lands, and which they could consume themselves without sharing it either with tenants or retainers" ( $W N$ III.iv.10, 418). Over time, as long-distance trade grew, the town became richer, it produced more manufactured goods, and many carried local agricultural surplus to foreign destinations. As this process occurred across large parts of Europe, overall trade expanded; and with this expansion of the market, so too the division of labor. The commercial trading economy grew richer. Feudalism disappeared in these areas.

\subsection{Interpreting the Transformation of the Towns}

To explain the towns' escape from the violence of the feudal basic natural state, I draw on the two different but complementary arguments of the microinstitutional level involving organizations, and the macroinstitutional level involving political exchange and the (small c) constitution. Addressing changes at both levels is necessary to understand the rise and economic growth of towns. 


\subsubsection{Microinstitutional Analysis}

The microinstitutional level involves the organizational revolution following the towns' provision of liberty, exploiting commercial opportunities, and enhancing security. Building commercial towns capable of providing liberty, maintaining security, and supporting long-distance trade required an organizational revolution - the growth of the civil society - with dozens if not hundreds of new types of organizations. Moreover, the sets of organizations must also fit together in the sense that they complement one another rather than get in each other's way or, worse, plunder and fight one another. Organizations direct and coordinate the efforts of people to produce the outcomes we characterize as liberty, wealth, and security. We have too little theory that explains how separate but complementary public organizations work together to create the market infrastructure necessary for a functioning society capable of long-term economic growth.

Although economic theory does a good job of modeling the interaction of economic organizations in modern markets in states characterized by the rule of law and other market infrastructure, we lack the extensions of this theory to include political and social organizations, especially those organizations that provide market infrastructure, a civil society helping to maintain the town organization (North, Wallis, and Weingast [2009, ch. 4], provides an initial attempt for open-access orders).

\section{The Medieval Town as an Organization of Organizations}

Town organization, in contrast to feudal organization, exhibits much greater specialization. At the highest level, the town's corporate charter formed the town as an organization vested with various rights, including the right to self-governance and to provide security. All other town organizations flow from this charter, making the town an organization of organizations. Many of these organizations were independent of the state, although sanctioned by the official system, which restricted access to organizations to specific classes of people for specific purposes.

Consider the basis for implementing each of the three revolutions associated with the towns: liberty, commerce, and security.

Liberty. Liberty is a term that has fallen into disuse in economics. In the mid- to late twentieth century, many of the great economists used it; notably, James M. Buchanan and Friedrich Hayek. Smith also used this term (see Aspromourgos 2009, 223-38; Forbes 1975; see also Lieberman 2006; Rothschild and Sen 2006, 334-37) in a way that parallels issues raised in the modern literatures on economic development and economic history, for example, by Douglass North (1990); namely, liberty as freedom from preda- 
tion, expropriation, and arbitrary action by the state, therefore allowing secure property rights and contract enforcement. ${ }^{24}$

The town's right to self-government was vested in its charter. Town government was more highly differentiated than that in the surrounding countryside. Each of its functions was embodied in organizations, including a form of governing body, an executive, and a judiciary.

If commerce represents the development of markets in Smith's approach, liberty and security provided the legal and military infrastructure necessary to sustain markets. As sections 2.4 and 2.5 demonstrate, Smith argued that markets require the legal infrastructure of justice, secure property rights, and protection from predation. Commerce and economic growth also depend on a military advantage by which the commercial society could defend itself in a world of hostile groups, both internal and external.

Although Smith does not explain how, the system of liberty provided for perpetuity and impersonality (at least for the elite), two critical ingredients in the rule of law and the doorstep conditions that represent important elements of the political economics of development (Weingast 2010). Liberty also provided merchants with the incentives to specialize, to engage in longdistance trade, and to accumulate capital. The towns experienced economic growth in two related senses. The economy grew through division of labor and capital accumulation, but also through extension into the surrounding countryside.

Commerce. Although Smith does not discuss this aspect of town organization, central to the towns' economic and political success were the guild organizations and merchant firms. These organizations created and coordinated much of the towns' economic activities and many of the political functions. In addition, the trading towns created the exchanges represented in long-distance trade. All of this had to be organized efficiently so that the towns could compete successfully on the international market and with neighboring towns, which were often close substitutes.

The infamous apprenticeship system represented another set of organizations at once creating barriers to entry, ensuring the education of an apprentice into the skills of the trade or craft, and organizing the entry of potentially talented individuals into the business. Smith famously criticized this system (e.g., $W N$ I.x.c.1-17, 135-40). The system of guild restrictions and the apprenticeship system remind us that the towns were far from modern open-access orders.

Security. Each town also had a carefully crafted set of military organization necessary to provide security for the town and the surrounding countryside, especially as the town's umbrella expanded over time. Survival required that

24. His definition of liberty is, of course, not the sole one. 
the town possess a military organization superior to that of the lords in the surrounding countryside.

In addition to these sets of organizations, towns made use - indeed, often required - a wide range of other organizations. Some provided public goods, such as schools and hospitals. Other organizations involved various products and services sought after by citizens, such as clothing, shoes, linens, ale houses, inns, and food establishments. Finally, the church was generally represented through organizations, notably the local parish. Over time, as the towns grew larger, other church organizations established a presence in the towns, such as the mendicant order. ${ }^{25}$

\subsubsection{Macroinstitutional Analysis: Political Exchange and the Constitution}

The macroinstitutional or constitutional level involves the forces that foster the movement from basic natural state of feudalism to that of the towns on the doorstep. The political exchange between king and towns created a new constitutional order for the towns - the corporate form of organization - essential to the towns' success. In particular, I explain the macrolevel forces underlying the towns' escape from the violence trap (Cox, North, and Weingast 2017).

In this subsection, I interpret Smith's account of the feudal equilibrium and initiation of the transformation to the commercial economy. In North, Wallis, and Weingast's (2009) terms, the feudal equilibrium was a natural state with low levels of the division of labor and hence quite poor. Many localities experiencing considerable violence were fragile natural states, while the more stable ones were basic natural states. All secular organizations were directly associated with the dual military-economic hierarchy.

Arbitrary use of authority by the lords, known in modern terms as executive moral hazard, was a major problem during feudalism, and at many levels, ${ }^{26}$ for example, the local lord was at once the local executive, lawmaker, and judge with all the problems of governance that such an arrangement implies. As we have seen, predation was an omnipresent problem; fighting and violence characterized this world. In Adam Smith's view, the feudal world provided minimal incentives for investment, specialization, and exchange. Most people lived at subsistence.

Liberty, commerce, and security brought the towns from fragile and basic natural states to a state on the doorstep. They engineered perpetuity, both of the state and of organizations. The result was rule of law (at least for the elite), the growth of the commercial economy, and control of the military.

25. On the institutions and organizations of the medieval church, see Ekelund, Hébert, and Tollison (2006). In Weingast (2017), I explain Smith's approach to how the church contributed to the stability of the no-growth feudal equilibrium. See also Hont $(2009,164)$.

26. Besley and Persson (2011) provide an extended study of the relationship of executive moral hazard and economic performance. 


\subsubsection{The Emergence of Towns}

The towns also engineered political development, creating new governance structures that differed radically from those of the feudal system. I define political development as involving the increases in state capacity that provides the market infrastructure necessary for the economic development of markets. This state capacity must therefore include the ability to protect property, to enforce contracts, and to provide security without the threat of predation (Besley and Persson 2009). As we have seen, the growth of towns involved all these features. Perpetuity, impersonality, and inclusion in governance all appeared to varying degrees. These changes resulted in justice, secure property rights, and mechanisms for contract enforcement within the towns. Economic and political development proceeded in tandem, fostering investments, specialization and exchange, economic integration, and the growing reach of markets and the price mechanism (WN III.iv).

The towns' economic and political development arose simultaneously as part of a single process; neither antedated nor caused the other. Smith appreciated the "reciprocal relationship between commerce and liberty," and much of The Wealth of Nations examines how economic liberty fostered "the growth and diffusion of commercial prosperity," especially Books I, II, and IV (Winch 1978, 70). Nonetheless, as Winch argues, the literature has neglected Smith's arguments about the reverse relationship, namely how commerce helped promote liberty and property rights (Winch 1978, 70). ${ }^{27}$

The political exchange between king and towns granted the towns the ability to make nonincremental changes that, in turn, allowed the towns to enter the positive feedback loop leading to a new and better equilibrium than feudalism. The political exchange altered the condition of the towns sufficiently that they became more powerful than the local lords. A central feature of the towns' economy was economic integration. The specialists in long-distance trade depended on the towns' military organization for security and the towns' economy for many raw materials and food. Local specialists in food and raw products depended on the towns' demand for their products. Put in Smith's terms, economic integration at once expanded the "extent of the market," creating greater division of labor and fostering investment, all features of economic growth..$^{28}$

In terms of the violence trap, economic integration raised the economic costs of violence. High costs of violence lowered the value of violence,

27. Skinner, an exception, explains that the arrangements Smith "had themselves been developed and protected in an attempt to solve a political problem" generated from the economic desire to foster trade (Skinner 1975, 164). Many of Smith's contemporaries connected commerce and liberty, including Montesquieu ([1748] 1989), Hume (1985a, 1985b), Cantillon ([1755] 1959), and Bonnot ([1776] 2008). Hirschman (1977) reviews this literature.

28. Smith clearly understood the nature of economic integration. For example, he explains the surprising level of economic integration in the modern commercial economy through his analysis of all the inputs necessary to produce a woolen coat (WN I.i.11, 22-24). See Kennedy (2010, ch. 6, especially table 6.1) for an extensive discussion. 
hence giving disputing parties the incentives to solve their problems nonviolently. Moreover, the towns had strong incentives to expand markets. As they extended their reach into the countryside, the towns sought to earn profits from long-distance trade and from encouraging local marketization that transformed local, highly inefficient, and self-sufficient agriculture into market specialists. The towns typically did not use their military might to become another type of local lord who extracted from the local economy. Instead, the towns used their economic and military power to create markets and political freedom (for the elite, at least).

The opportunities for expanding commerce made possible a new form of political exchange, producing new political institutions governing the towns. These political institutions, in turn, fostered the townsmen's ability to exploit new economic opportunities provided by trade. Here, too, political and economic development is inextricably intertwined, reflecting Winch's "reciprocal relationship."

The nonincremental change - reflecting simultaneous changes in perpetuity, impersonality, inclusion, and in investment, specialization and exchange, and military organization-allowed the towns to escape the violence trap and enter the positive feedback loop. Once the towns were organized and generated sufficient security, they extended their reach into the countryside, increasing the size of the market and the division of labor. Expanding longdistance trade increased the towns' wealth. All these changes led the towns to extend yet again the reach of a larger security umbrella, with greater expansion of its reach into the countryside, further deepening the division of labor, and so on through the positive feedback loop. The result, as Winch argues, is that the "Commercial society is not merely one in which more people are engaged in producing capital goods ... it is one in which more people are drawn into the wider circle of commercial relationships. It is the situation arrived at once the division of labor has been thoroughly established, and men can supply only part of their needs from their own produce. It is the form of society in which "every man . . lives by exchanging, or becomes in some measure, a merchant"” (Winch 1978, 80; quoting WN I.iv.1, 37).

Another factor contributed to perpetuity; namely, towns expanded inclusion beyond a narrow elite in comparison with the feudal world, although it did not come close to achieving open access. For one, the towns absorbed many from the countryside in their market system, allowing the towns and markets to draw on a larger talent pool. The very specialized apprenticeship system organized by the guilds did the same thing for the most specialized production and merchant activities.

\subsection{Conclusions}

Adam Smith's Wealth of Nations is, among many other things, a study in why so many countries remain poor and why a few have become "opulent" or rich. Smith addressed this question in many different ways in his ram- 
bling work. Although many scholars focus on just one of these discussions, Smith's discussions make it hard to say any one of his answers is the definitive explanation. In Book I, he explains how the division of labor produces opulence. In Book II, he emphasizes the importance of savings and capital accumulation. Book IV emphasizes the central importance of appropriate public policies, explaining, for example, why mercantilism hinders a state's progress toward opulence in comparison to free trade. Each of these arguments resonates with modern economics. Further, each presumes a context of a state with high state capacity; namely, a serviceable judiciary, property rights, and liberty — Smith's "peace, easy taxes, and a tolerable administration of justice" (as reported by Stewart [1793] 1982, 322).

The force of this chapter is that Smith provides a fourth component explaining why so many countries fail to become opulent, one that differs in kind from the other three. In Book III of The Wealth of Nations, Smith discusses the necessary political foundations of markets and how, absent these foundations, countries cannot grow. He presents this argument, not in the abstract as he does with, say, the division of labor, but in a historical narrative about feudalism and the rise of towns. Smith embeds in the narrative a theory that drives the logic of the development of a commercial society out of the natural state of feudalism.

In this chapter, I interpret Smith's argument as a form of violence trap. Indeed, the no-growth feudal equilibrium was based on the violence trap. The prevalence of violence meant that property rights were insecure, as, therefore, were savings, investment, and innovation. In this world, most people lived at subsistence level. No one, neither king nor great lord, was capable of providing order.

The towns arose through political exchange between king and towns that granted them the right to a corporative form of self-governance. This exchange allowed the towns to make nonincremental changes, fostering their escape from the violence trap through a threefold revolution that simultaneously created liberty (including justice and the security of property rights), commerce, and hence economic growth, and security from the menacing outside world. All three were necessary for the towns' escape. The towns grew through long-distance trade, specialization and exchange, capital accumulation, and expansion into the local countryside where they helped transform the local economy from poor, self-sufficient agriculture into specialists in food and inputs into manufacturing shipped to the town and often entering long-distance trade.

The central elements of Smith's argument of the escape from the violence trap are as follows: The incorporation of towns in the context of political exchange with the king allowed them to enter the positive feedback loop of economic growth. The political exchange granted the towns the ability to enhance state capacity through nonincremental changes in security and investment in economic activities. The towns' more effective military 
organization subdued the local lords, expanding both long-distance trade and trade with the local countryside. As the towns extended their security umbrella, the local countryside experienced a nonincremental increase in the security of property rights, with incentives for investment, hard work, and exchange. The towns also transformed what Smith called "unproductive labor" (labor facing predation that had no incentive to work hard or invest) into productive labor. At the same time, as the local lords came under the towns' jurisdiction, they no longer needed their expensive retainers for defense. As they demilitarized, the lords became consumers, expanding the demand for the traders' goods and services. The demand for luxury goods by the lords also facilitated this process.

Towns also represented an explosion of new organizations - the corporate form, as mentioned, the overall government, specific units within the government, such as the executive, the judiciary, and a town council. Merchants organized their guilds and their firms, and the towns' military organization provided defense. The church also had its organizational reach into the towns. As noted above, the town became an organization of organizations. In Levy's (chapter 3, this volume) terms, towns can be seen as organizations at once in vertical competition with the local lords and an oppositional, if generally cooperative one, with the king. As with Levy's analysis of the privileges of the corps intermédiaires, towns gained privileges, but ones that helped them sustain a better or more opulent social and economic outcome.

The explanation provided of the escape from violence satisfies the three conditions mentioned at the outside for a theory of the initiation of political economics of development: a microlevel analysis of the organizations providing the heavy lifting of ensuring the various parts of the movement to the doorstep conditions occurred; a macrolevel analysis of the political exchange and constitution necessary to make the escape work; and an analysis showing why the new arrangements were stable; that is, an equilibrium, so that the towns were not a temporary aberration that would fall back into the old, feudal equilibrium.

Adam Smith's discussion of the transformation of feudalism to the commercial society fits well with aspects of the emerging literature on the political economics of development, and it adds ideas relatively lacking. Economic and political development are not separate tasks in Smith's view, but inextricably intertwined as a single process (see such diverse scholars as Acemoglu and Robinson [2006, 2012]; Bates [2001]; Besley and Persson [2009, 2011]; Tilly [1992]). Attempts to reform one without reform of the other generally fail. Smith's view of the rise of towns and the commercial society out of feudalism demonstrates that the escape from the poverty and violence required simultaneous changes in the economy, polity, and in security. When the three elements coexist, growing opulence is the result. Similarly, when any of the three elements is missing, growing opulence fails.

Finally, the central importance of violence in Smith's approach is rela- 
tively lacking in the literature (North, Wallis, and Weingast 2009). ${ }^{29}$ Reflecting the trade-off between security and efficiency, societies facing existential threats take actions to defend themselves, and these actions - as Smith argues - force substantial deviations from political institutions and policies that generate opulence or long-term economic growth. Put simply, Smith argued that feudal Europe failed to develop due to violence and oppression.

\section{Abbreviations}

The works of Adam Smith. All references to the Glasgow edition, as reprinted by the Liberty Fund.

LJ Smith, Adam. 1762-63; [1767] 1981. Lectures on Jurisprudence, edited by R. L. Meek., D. D. Raphael, and P. G. Stein. Indianapolis: Liberty Fund. The lecture notes are comprised of two parts:

$L J(\mathrm{~A}) \quad$ The first set of lecture notes, corresponding to the 1762-63 term;

$L J(B) \quad$ The second set of lecture notes, dated 1767 though thought to correspond to the 1763-64 term.

WN Smith, Adam. [1776] 1981. An Inquiry into the Nature and Causes of The Wealth of Nations, edited by R. H. Campbell, A. S. Skinner, and W. B. Todd. Indianapolis: Liberty Fund.

\section{References}

Acemoglu, Daron, and James A. Robinson. 2006. "Economic Backwardness in Political Perspective." American Political Science Review 100:115-31. 2011. Why Nations Fail. New York: Crown Business.

Allen, Robert C. 2009. The British Industrial Revolution in Global Perspective. Cambridge: Cambridge University Press.

Alston, Lee J., Bernardo Mueller, Marcus Melo, and Carlos Pereira. 2016. Beliefs, Leadership and Critical Transitions; Brazil, 1964-2012. Princeton, NJ: Princeton University Press.

Aspromourgos, Tony. 2009. The Science of Wealth: Adam Smith and the Framing of Political Economy. London: Routledge.

Azariadis, Costas, and John Stachurski. 2005. "Poverty Traps." In Handbook of Economic Growth, vol. 1A, edited by Philippe Aghion and Steven N. Durlauf. Amsterdam: Elsevier.

Barzel, Yoram. 1997. Economic Analysis of Property Rights. Cambridge: Cambridge University Press.

29. Exceptions exist to the dominant view that ignores violence, notably, Collier (2007), Cox, North, and Weingast (2017), Dixit (2004), and Hirschleifer (1994). Other exceptions involve rationalist explanations for interstate war (Fearon 1995; Powell 1999; Wittman 2009) and a large literature on the relationship between interstate conflict and development outside of economy (e.g., Acemoglu and Robinson 2012; Bates 2001; Besley and Persson 2009, 2011; Tilly 1992). 
2002. The Theory of the State. Cambridge: Cambridge University Press.

Bates, Robert H. 2001. Prosperity \& Violence: The Political Economy of Development. New York: W. W. Norton.

Bates, Robert H., Avner Greif, Margaret Levi, Jean-Laurent Rosenthal, and Barry R. Weingast. 1998. Analytic Narratives. Princeton, NJ: Princeton University Press.

Bell, Joe A. 1992. "Adam Smith's Theory of Economic Development: 'Of the Natural Progress of Opulence."' Journal of Economics and Finance 16 (1): 137-45.

Besley, Timothy, and Torsten Persson. 2009. "The Origins of State Capacity: Property Rights, Taxation, and Politics.” American Economic Review 99 (4): 1218-44.

2011. Pillars of Prosperity. Princeton, NJ: Princeton University Press.

Blaug, Mark. 1978. Economic Theory in Retrospect, 3rd ed. Cambridge: Cambridge University Press.

Bonnot, Étienne, Abbé de Condillac. (1776) 2008. Commerce and Government Considered in Their Mutual Relationship. Indianapolis: Liberty Fund.

Brue, Stanley L., and Randy R. Grant. 2007. The Evolution of Economic Thought, 7th ed. Mason, OH: Thomson South-Western.

Cantillon, Richard. (1755) 1959. An Essay on the Nature of Commerce in General. London: Frank Cass and Co., Ltd.

Collier, Paul. 2007. The Bottom Billion: Why the Poorest Countries Are Failing and What Can Be Done About It. Oxford: Oxford University Press.

Cox, Gary W., Douglass C. North, and Barry R. Weingast. 2017. "The Violence Trap: A Political-Economic Approach to the Problems of Development." Unpublished manuscript.

Dixit, Avinash K. 2004. Lawlessness: Alternative Modes of Governance. Princeton, NJ: Princeton University Press.

Ekelund, Robert B., Jr., Robert F. Hébert, and Robert D. Tollison. 2006. The Marketplace of Christianity. Cambridge, MA: MIT Press.

Eltis, W. A. 1975. "Adam Smith's Theory of Economic Growth.” In Essays on Adam Smith, edited by Andrew S. Skinner and Thomas Wilson. Oxford: Clarendon Press.

Fearon, James D. 1995. "Rationalist Explanations for War.” International Organization (Summer) 49: 379-414.

Forbes, Duncan. 1975. Hume's Philosophical Politics. Cambridge: Cambridge University Press.

Haakonssen, Knud. 1981. The Science of a Legislator: The Natural Jurisprudence of David Hume and Adam Smith. Cambridge: Cambridge University Press.

Henderson, Willie. 2006. Evaluating Adam Smith: Creating the Wealth of Nations. London: Routledge.

Hirschleifer, Jack. 1994. "The Dark Side of the Force." Economic Inquiry 32:1-10.

Hirschman, Albert O. 1977. Passions and the Interests: Political Arguments for Capitalism before Its Triumph. Princeton, NJ: Princeton University Press.

Hollander, Samuel. 1973. The Economics of Adam Smith. Toronto: University of Toronto Press.

1979. "Historical Dimension of The Wealth of Nations." In Adam Smith and Modern Political Economy: Bicentennial Essays on The Wealth of Nations, edited by Gerald P. O’Driscoll, Jr. Ames: Iowa State University Press.

Hont, Istvan. (1989) 2005. "Adam Smith and the Political Economy of the 'Unnatural and Retrograde' Order." In The Jealousy of Trade. Cambridge, MA: Harvard University Press.

_ 2009. "Adam Smith's History of Law and Government as Political Theory." In Political Judgement: Essays for John Dunn, edited by R. Bourke and R. Geuss. Cambridge: Cambridge University Press. 
2015. Politics in Commercial Society: Jean Jacques Rousseau and Adam Smith. Edited by Béla Kapossy and Michael Sonenscher. Cambridge, MA: Harvard University Press.

Hume, David. (1752) 1985a. “Of Commerce.” Essay I, Part II. In Essays: Moral, Political, and Literary, edited by Eugene Miller. Indianapolis: Liberty Fund.

. (1752) 1985b. "Of Refinement in the Arts." Essay II, Part II. In Essays: Moral, Political, and Literary, edited by Eugene Miller. Indianapolis: Liberty Fund.

Kennedy, Gavin. 2010. Adam Smith, 2nd ed. Houndmills, UK: Palgrave Macmillan. Levi, Margaret. 1988. Of Rule and Revenue. Berkeley: University of California Press.

Lieberman, David. 2006. "Adam Smith on Justice, Rights, and Law." In The Cambridge Companion to Adam Smith, edited by Knud Haakonssen. Cambridge: Cambridge University Press.

Macfarlane, Alan. 2000. The Riddle of the Modern World: Of Liberty, Wealth and Equality. London: Palgrave.

Montesquieu, Charles de. (1748) 1989. The Spirit of the Laws. Translated and edited by Anne M. Cohler, Basia Carolyn Miller, and Harold Samuel Stone. New York: Cambridge University Press.

Moss, Laurence S. 1979. "Power and Value Relationships in The Wealth of Nations." In Adam Smith and Modern Political Economy: Bicentennial Essays on the Wealth of Nations, edited by Gerald P. O'Driscoll. Ames: Iowa State University Press.

Muthoo, Abhinay. 1999. Bargaining Theory with Applications. Cambridge: Cambridge University Press.

Myint, Hla. 1977. "Adam Smith's Theory of International Trade in the Perspective of Economic Development." Economica 44 (175): 231-48.

North, Douglass C. 1981. Structure and Change in Economic History. New York: Norton.

-1990. Institutions, Institutional Change, and Economic Performance. Cambridge: Cambridge University Press.

2005. Understanding the Process of Economic Change. Princeton, NJ: Princeton University Press.

North, Douglass C., and Robert Paul Thomas. 1973. The Rise of the Western World: A New Economic History. Cambridge: Cambridge University Press.

North, Douglass C., John Joseph Wallis, and Barry R. Weingast. 2009. Violence and Social Orders: A Conceptual Framework for Interpreting Recorded Human History. New York: Cambridge University Press.

Ober, Josiah, and Barry R. Weingast. Forthcoming. "The Sparta Game: Violence, Proportionality, Austerity, Collapse." In How to Do Things with History, edited by Paul Millett. Oxford: Oxford University Press.

O’Brien, D. P. (1975) 2004. "The Smithian Growth Process." The Classical Economists Revisited. Princeton, NJ: Princeton University Press.

Olson, Mancur. 1993. "Democracy, Dictatorship, and Development." American Political Science Review 87 (3): 567-75.

Posner, Richard. 2006. Economic Analysis of Law. 7th ed. Austin, TX: Wolters Kluwer/Aspen Publishers.

Powell, Robert. 1999. In the Shadow of Power: States and Strategies in International Politics. Princeton, NJ: Princeton University Press.

Robbins, Lionel. 1998. A History of Economic Thought: The LSE Lectures, edited by Steven G. Medema and Warren J. Samuels. Princeton, NJ: Princeton University Press.

Rothschild, Emma, and Amartya Sen. 2006. "Adam Smith's Economics." In The 
Cambridge Companion to Adam Smith, edited by Knud Haakonssen. Cambridge: Cambridge University Press.

Schumpeter, Joseph A. 1954. History of Economic Analysis. New York: Oxford University Press.

Skinner, Andrew S. 1975. "Adam Smith: An Economic Interpretation of History." In Essays on Adam Smith, edited by Andrew S. Skinner and Thomas Wilson, pp. 155-78. Oxford: Clarendon Press.

1996. A System of Social Science: Papers relating to Adam Smith. New York: Oxford University Press.

Stewart, Dugald. (1793) 1982. "Account of the Life and Writings of Adam Smith, LL.D." From the Transactions of the Royal Society of Edinburgh (edited by I. S. Ross). In Adam Smith: Essays on Philosophical Subjects, edited by W. P. D. Wightman and J. C. Bryce. Indianapolis: Liberty Classics.

Tilly, Charles. 1992. Coercion, Capital, and European States, AD 990-1992, rev. ed. Cambridge, MA: Blackwell.

Weingast, Barry R. 1995. "The Economic Role of Political Institutions: MarketPreserving Federalism and Economic Development." Journal of Law, Economics, and Organization 11 (Spring 1995): 1-31.

. 2010. "Why Developing Countries Prove So Resistant to the Rule of Law." In Global Perspectives on the Rule of Law, edited by James J. Heckman, Robert L. Nelson, and Lee Cabatingan. New York: Routledge.

2017. "Adam Smith's Industrial Organization of Religion: Explaining the Medieval Church's Monopoly and Its Breakdown in the Reformation." Working Paper, Hoover Institution, Stanford University.

Winch, Donald. 1978. Adam Smith's Politics: An Essay in Historiographic Revision. New York: Cambridge University Press.

Wittman, Donald. 2009. "Bargaining in the Shadow of War: When Is a Peaceful Resolution Most Likely?" American Journal of Political Science 53 (3): 588-602.

Young, Allyn A. 1928. "Increasing Returns and Economic Progress." Economic Journal 38 (152): 527-42. 